\title{
FUNDRAISING STRATEGIES IN THE NATIONAL BOARD OF ZAKAT (BAZNAS) TANA TORAJA REGENCY
}

\section{Trisno Wardy Putra ${ }^{1^{*}}$}

${ }^{1}$ Faculty of Islamic Economics and Business, Alauddin State Islamic University of Makassar

Abstract: Zakat is an obligation for a Muslim and is included in the five pillars of Islam. Zakat has a strategic role, namely helping the government handle the poor. This study describes collecting zakat funds in the Amil Zakat Agency of Tana Toraja Regency, a Muslim minority area. In this study, the method used was qualitative, where the researcher conducted direct interviews with the respondents. The results showed that the fundraising strategy at the National Amil Zakat Agency in Tana Toraja Regency was not optimal. Therefore, the researcher recommends that Amil BAZNAS Tana Toraja Regency hold a digital fundraising training for zakat.

Keywords: Fundraising Strategies; Zakat; Baznas Toraja

Corresponding author: trisno.putra@uin-alauddin.ac.id

Received: August 08, 2021; Accepted: December 18, 2021; Published: December 28, 2021

Abstract: Zakat merupakan kewajiban seorang muslim dan termasuk dalam lima rukun Islam. Zakat mempunyai peranan yang strategis, yakni membantu pemerintah dalam hal penanganan warga yang kurang mampu. Penelitian ini bertujuan mendeskripsikan strategi pengumpulan dana zakat di BAZNAS Kabupaten Tana Toraja yang merupakan daerah minoritas muslim. Dalam penelitian ini metode yang digunakan adalah kualitatif dimana peneliti melakukan wawancara langsung kepada responden. Hasil penelitian menunjukan bahwa strategi fundraising di Badan Amil Zakat Nasional Kabupaten Tana Toraja belum begitu maksimal. Sehingga peneliti merekomendasikan agar Amil BAZNAS Kabupaten Tana Toraja untuk mengikuti pelatihan-pelatihan terkait penghimpunan dana zakat melalui digital.

Keywords:Srategi Fundraising; Zakat; Baznas Toraja 


\section{INTRODUCTION}

Islam teaches us that wealth should not flow only among the rich [Surah Al-Hashr (59): 7]. Rich people have an obligation to benefit others, so that they cannot neglect their needy and poor brethren. Poverty is very dangerous for human life because it affects beliefs, beliefs, morals, behavior, conscience, and thoughts and encourages people to sin. (Cokrohadisumarto et al., 2020). In Islam, one of the important socio-economic and religious practices aimed at preventing the concentration of wealth in the hands of a few is the imposition of zakat (Bin-Nashwan, Abdul-Jabbar, Aziz, \& Sarea, 2020). Development and poverty have become important issues in economic, social, and political research around the world, especially in developing countries, including countries with large Muslim populations. Various parties from various organizations, including the United Nations, work to alleviate poverty through various activities, service programs, and policies. (Rahmat \& Nurzaman, 2019).

In the Qur'an, Surah At-Taubah 34, Az-Zariyat 19 and Surah Al Maun 1-2, Zakat is said to be an obligation of worship and the third pillar of Islam. In addition to the Qur'an, there are several hadiths that require zakat. "Allah obliges them (Yemen) to pay zakat in exchange for wealth, and zakat is taken from the rich and distributed among the people." The Prophet also said that paying zakat is sacred, purifying, and related to relatives, neighbors, and those closest to them. Respect the rights of the poor. Three actors who are directly related to zakat worship, including Muzzaki, Mustahiq, and Amil, Zakat, mustahiq, and amil are names for people or institutions that manage and distribute zakat assets. In carrying out zakat, there are several terms and conditions that must be met regarding muzzaki, mustahiq, and property that may be issued as zakat. (Fathonih et al., 2019).

Muslims who believe accept that Allah is the source of all gifts and wealth, and that $\mathrm{He}$ grants them His will (Sura al-Baqara 17:29).Therefore, the real owner of the earth's wealth is Allah. The payment of zakat is carried out with several objectives, including the following: to eradicate poverty and enforce socio-economic justice; protect wealth from the envy of others, especially the poor; purify one's wealth and remove attachments; and thank God for His bounty. (Samad \& Glenn, 2010).

Zakat can save its recipients from poverty, improve their standard of living, and move them to a higher social class if they are wisely invested in business and other economic activities that increase profits. Zakat recipients can maintain their dignity through zakat because they do not have to beg to live. Zakat also prevents them from falling into evil and enables social harmony. It strengthens fraternity by giving recipients a feeling of belonging to the community and reassuring them that others care about their well-being. Many of these and many others are some of the benefits that Zakat recipients receive. (Owoyemi, 2020)

The word zakat has been mentioned at least 20 times in the Qur'an. The Quran confirms In general, anyone who wants to practice Islam (Kafa) must pray and pay zakat. The equal emphasis between Zakat and the commandments of prayer means the inseparable similarities. This shows the generous progress of Islam (Rahmat \& Nurzaman, 2019). 
Even if you do not have Zakat authority at the state level, the payment of Zakat will carry out Allah's orders. Zakat institutions have played an important role in the socio-economic field. Moral and spiritual development throughout Islamic history Zakat is part of the Islamic economic system because it has a significant impact on the achievement of social services. Harmony and the maintenance of a decent standard of living for poor Muslims. (Sawmar \& Mohammed, 2021).

A Zakat payment is a liability on the productive wealth of individuals and businesses at a fixed rate of $2.5 \%$ of the assets that meet the Zakat requirements (for example, Muslim "nisab" to achieve. can meet the minimum threshold). There is wealth to own and perfect "transportation" from year to year). It is undeniable that zakat has a predetermined purpose. Zakat is worship and is one of the five pillars of Islam that has a real impact on social and economic welfare. You see it when the rich spend their income. Giving wealth in the form of zakat to the marginalized poor is a harmonious social interaction between all levels of society. The proper and fair distribution of zakat benefits those who cannot participate in economic activities. At the national level, zakat is considered a fundamental element of national tax policy. Employment is concentrated as a natural resource to help balance the national economy through a more equitable distribution of wealth and excess units of income (Bin-Nashwan, Abdul-Jabbar, Aziz, \& Viswanathan, 2020).

The National Financing Association (1996) defines financing as "raising assets and resources from multiple sources to support a particular organization or project." (Mahmood et al., 2005). Philanthropic fundraising has become a major business activity all over the world. Because fundraising is the only source of income for the center, a strong emphasis is placed on fundraising practices. The center employs a variety of fundraising methods, both traditional and modern. These include one-on-one contact and direct mail, as well as corporate fundraising, major gift donors, event fundraising, community fundraising, static and collection fundraising, online fundraising, direct response fundraising, educational fundraising, bequests, in memorial, and tribute giving. Each of these is discussed in detail below, beginning with the most important and progressing to the most minor (Yaacoub et al., 2015).

Charitable fundraising has become one of the most important business activities in the world. Financing is the only source of central income, so there is a lot of emphasis on funding practices. The center uses a variety of traditional and modern financing methods. This includes one-on-one contact and direct mail, as well as corporate fundraisers, grand prize donors, event fundraisers, community fundraisers, static fundraisers, online fundraisers, and direct response. including fundraisers, education fundraisers, inheritances, memorials, and commendations. The following describes each one, from the most commonly used to the smallest. The potential of national zakat itself is enormous. Based on the Zakat Potential Mapping Indicator (IPPZ), as of 2019, Indonesia's zakat potential was recorded at Rp. 233.8 trillion, or equivalent to $1.72 \%$ of GDP in 2018, which was valued at Rp. 13,588.8 trillion. In 2019, corporate zakat had a potential of Rp6.71 trillion. Then, in 2020, the potential for corporate zakat reaches Rp. 144.5 trillion. In other words, the total potential for zakat in Indonesia in 2020 is IDR 327.6 trillion (Baznas, 2020). The potential is quite enormous, and, of course, it can 
overcome the socio-economic problems currently engulfing this country. Because of that, zakat processing must be well organized so that zakat potential can be maximized.

Several studies have been conducted related to fundraising strategies in zakat institutions, which are predominantly Muslim. For example, Nopiardo analyzes fundraising strategies at BAZNAS Tanah Datar Regency, a Muslim-majority area (Nopiardo, 2018). Listanti, in his research on Fundraising Strategy Analysis in optimizing zakat receipts in Baitul Mal, West Aceh district, which is also a Muslim-majority area (Listanti et al., 2021). So, it is still rare for anyone to conduct research related to fundraising strategies in zakat management organizations whose areas are Muslim minorities.

BAZNAS Tana Toraja has been collecting, distributing and using zakat, infaq and alms since 2017. Tana Toraja Regency is an ethnic minority district based on the religious data of the Ministry of Religion of Tanatra Regency in 2018. The number of religious adherents is divided into 19 subsections. That is, 1 . Buddhist: $19=0.01 \%$. 2. Hindus: 10,214 (or 3.84\%).3. Muslims: 33,975 (or 12.77\% of the population).4. Catholics: 50 out of 158 (or 18.86\%)5. Christian: 171,646 people $=64.53 \%$ (Said, 2020). Based on the data above, special attention should be paid to the management of BAZNAS Tana Toraja to maximize the collection of Zakat funds. The limited number of muzakki candidates, coupled with a general lack of understanding about the obligation to pay zakat, becomes an obstacle to collecting zakat. It is hoped that this research will help BAZNAS Tana Toraja get more money from people who pay Zakat through them.

\section{RESEARCH METHODS}

Location and time

This research was conducted at the National Board of Zakat (BAZNAS) Tana Toraja Regency, from July 16, 2021, to July 31, 2021. This analysis is based on qualitative research methods and combines consultation with secondary sources (such as online newspapers and magazines, literature reviews, statistics, and reports by national authorities and international organizations) and interviews (Carboni et al., 2017). This study will use the origin of the main data and secondary data. Where the main data is obtained according to the questionnaire method, and secondary data is obtained according to literature studies in the form of books, journals, or scientific works, websites, and other materials related to zakat (Rahmat \& Nurzaman, 2019). 
Miles and Huberman describe the process of analyzing qualitative research dataas follows.

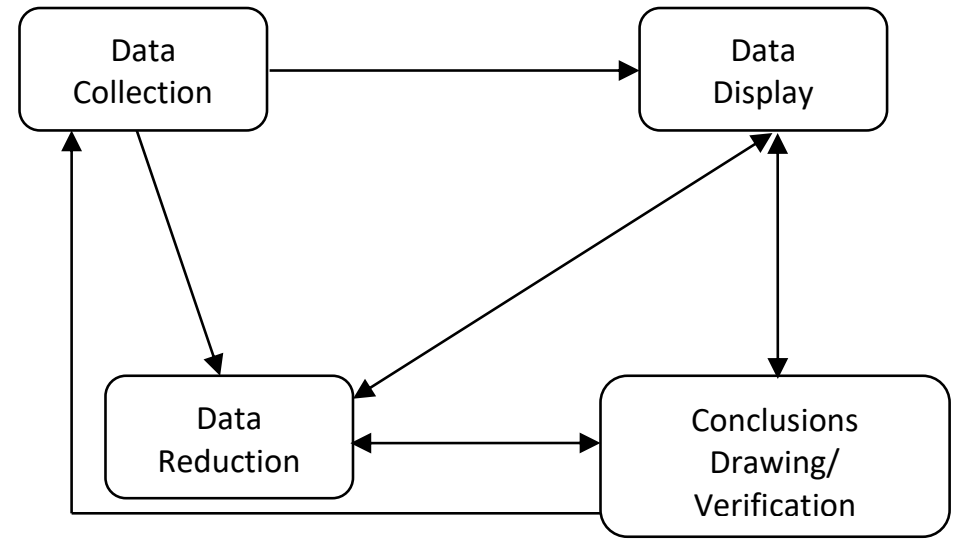

Source: Figure 1 Miles and Huberman's Qualitative Research Process

This figure shows the interactive nature of the data collected through data analysis, and that data collection is an integral part of the data analysis activity. Data reduction is the completion of the data, and then the data is classified into certain concept units, certain categories, and certain themes. Finally, the results of data reduction are processed so that they can be seen in the big picture. It can be in the form of a sketch, summary, matrix, or other format. To facilitate the presentation and confirmation of conclusions, Therefore, in this post I will answer and explain (1) the meaning of data analysis, (2) data analysis at the time of data collection, (3) data reduction, (4) data presentation, and (5) verification and conclusions. (Rijali, 2018).

\section{RESULTS AND DISCUSSION}

\section{Profile of the National Board of Zakat (BAZNAS) Tana Toraja Regency}

The National Board of Zakat (BAZNAS) Tana Toraja Regency is the official. It is a zakat management organization established by the government based on the Decree of the Tana Toraja Regent No. 245/IV/2017. It has the task and function of collecting and distributing zakat, infaq, and alms (ZIS) at the Tana Toraja Regency level as one of the regional technical institutions, The National Board of Zakat (BAZNAS) Tana Toraja Regency is located at J1. Merdeka No. 26, Bombongan, Makale, Tana Toraja Regency, South Sulawesi, and has a supporting element in carrying out specific tasks of the Tana Toraja Regency Government.

Deputy Chair III for Distribution, Hj. Masai Djabbar, and Deputy Chair IV for Human Resources Wahyudin Muhallim, S.Si, who have their main tasks and functions.Collection of Zakat Funds at the National Board of Zakat (BAZNAS) Tana Toraja Regency. The collection of zakat funds at the National Amil Zakat Agency of Tana Toraja Regency has increased every year, although, in 2019, it had decreased from 2018. The following is a cash report for zakat funds at BAZNAS Tana Toraja Regency for the last three years. 
Table 1. BAZNAS Zakat Fund Receipt for Tana Toraja Regency 2018-2020

\begin{tabular}{lcc}
\hline No. & Year & Fundraising \\
\hline 1 & 2018 & 97.974 .000 \\
2 & 2019 & 69.884 .000 \\
3 & 2020 & 134.505 .862 \\
& Total & $\mathbf{3 0 2 . 3 6 3 . 8 6 2}$
\end{tabular}

Source: BAZNAS Tana Toraja Regency(2018-2020)

From the table above, it can be seen that the zakat receipts carried out by BAZNAS in Tana Toraja Regency for the last three years, namely from 2018 to 2020, have fluctuated. For example, in 2018, the zakat funds collected were Rp. 97,947,000. Then in 2019, it decreased by about $28 \%$, or decreased by Rp. $28,090,000$. In 2020 , around $92 \%$, or an increase of around Rp64,621,862. Over the last three years, the zakat funds collected by BAZNAS Tana Toraja Regency totaled Rp. 302.363862,-..While the data on receipt of infaq funds is as follows:

Table 2. BAZNAS Fund Receipt for Tana Toraja Regency 2018-2020

\begin{tabular}{llc}
\hline No. & Year & Fundraising \\
\hline 1 & 2018 & 58.305 .000 \\
2 & 2019 & 43.050 .000 \\
3 & 2020 & 35.709 .275 \\
& Total & $\mathbf{1 3 7 . 0 6 4 . 2 7 5}$ \\
\hline
\end{tabular}

Source: BAZNAS Tana Toraja Regency(2018-2020)

Meanwhile, the infaq receipts carried out by BAZNAS in Tana Toraja Regency for the last three years, namely from 2018 to 2020, have decreased. In 2018 the zakat funds collected were Rp. $58,305,000$. Then in 2019 , it decreased by about $26 \%$ or decreased by Rp. 15.255.000. In 2020, it decreased again by around $17 \%$ or decreased by Rp. $7,340,725$. Overall, the infaq funds that BAZNAS Tana Toraja Regency has collected over the last three years amounted to Rp137,064,275.

Table 3. Receipt of Zakat and Infaq Funds BAZNAS Tana Toraja Regency 2018-2020

\begin{tabular}{|ccccc|}
\hline No. & Year & \multicolumn{2}{c}{ Fundraising } & Total \\
& & Zakat & Infaq & \\
1. & 2018 & 97.974 .000 & 58.305 .000 & 156.297 .000 \\
2. & 2019 & 69.884 .000 & 43.050 .000 & 112.934 .000 \\
3. & 2020 & 134.505 .862 & 35.709 .275 & 170.215 .137 \\
& Total & $\mathbf{3 0 2 . 3 6 3 . 8 6 2}$ & $\mathbf{1 3 7 . 0 6 4 . 2 7 5}$ & $\mathbf{4 3 9 . 4 4 6 . 1 3 7}$ \\
\hline
\end{tabular}

Source: BAZNAS Tana Toraja Regency(2018-2020) 
Overall, the amount of zakat and infaq funds collected by the National Amil Zakat Agency of Tana Toraja Regency from year to year also fluctuated. The amount that has been collected over the last three years is Rs. 439,446,137. According to the Chairman of BAZNAS, the potential for zakat in Tana Toraja as a whole reaches Rp1,000,000,000/year. It means that it is only approximately $1.94 \%$ of the existing zakat potential between the potential and the collection for a year. Due to inadequate public awareness regarding the obligation to pay zakat, the Tana Toraja district is an area with a Muslim minority.

\section{Fundraising Strategy at the National Amil Zakat Agency of Tana Toraja Regency}

In carrying out fundraising activities, many methods and techniques can be used. As for the method, this is a typical form of activity carried out by an organization to collect funds from the community. This method can basically be divided into two types, namely direct fundraising and indirect. Direct Fundraising Method (Direct Fundraising) What is meant by this method is methods that use techniques or ways that involve participation in muzakki directly. That is the form of fundraising in which the interaction and the accommodation power of the muzakki response can be immediately (immediately) done. Indirect Fundraising Method (Indirect fundraising) This method is a method that uses techniques or methods that do not involve direct participation in muzakki. That is, the forms of fundraising were not done with providing direct accommodation power to Muzakki's instantaneous response (Nopiardo, 2018)

Fundraising strategies carried out by management institutions for zakat in increasing the acceptance of zakat funds vary. Donors (muzakki) get to know each other and groups of donors (muzakki) through direct and group socialization, as well as marketing campaigns that are either direct or indirect, electronic or print media, and a muzakki conner app for Android and iPhone phones (Listanti et al., 2021) . In addition, the strategy for collecting zakat funds can be carried out in the following ways: Formation of a Zakat Collection Unit (UPZ) It is done to make it easier to collect zakat, both for zakat management institutions in reaching the muzakki and for the muzakki in paying zakat by opening the zakat receipt counter. Zakat management institutions can open a counter or counter where zakat payment is made at the office or secretariat of the institution concerned. bank account opening. What is needed to be noted here is that in opening accounts, funds should be separated between each account so that this will make it easier for Mukki in the delivery of zakat (Nopiardo, 2018)

Fundraising activities collect zakat, infaq, and alms funds from muzakki and munfik and distribute them to zakat management organizations to be distributed to those entitled to receive it (mustahik) according to their respective sizes. The collection of zakat, infaq, and alms funds is carried out by the National Amil Zakat Agency of Toraja Regency using several strategies: First, socialization. Through outreach to the community office, social media, and posters in mosques, the community With the implementation of this socialization program, it is hoped that the community will understand the obligation to pay tithe. However, most Muslims do not fully understand the obligation to pay tithe, so the awareness to pay tithe is still lacking. Because they think that zakat is only issued in 
the month of Ramadan, even though zakat mal is issued when it has reached its haul and nishab.

Second, cooperation. In order to increase fundraising at BAZNAS, Tana Toraja Regency collaborates with various government agencies (SKPD) in Tana Toraja Regency by forming a Zakat Collection Unit (UPZ) in several agencies. However, only three agencies distribute zakat in the National Baznas, namely, the Tana Toraja Ministry of Religion Office, the Religious Courts, and the High Prosecutor's Office, so that the collection of zakat funds is still not optimal. The third bank account is to make it easier for muzakki or hypocrites to deposit their zakat and infaq to BAZNAS, Tana Toraja Regency. Amil has prepared a bank account and mobile number to confirm the amount of funds to be distributed. It is very important that the Tana Toraja Regency's BAZNAS can be properly managed so that the data that comes into them can be properly handled.

The banks and account numbers prepared by BAZNAS of Tana Toraja Regency are as follows: BNI Bank: 3232337778, BRI Bank: 2190-01-005891-53-2, and Bank Mandiri: 170-00-0979979-6. Fourth, Consultation Services and Zakat Collection: Apart from the three methods above, BAZNAS Tana Toraja Regency also provides consultation and pick-up services for zakat by contacting the Contact Center: +6282271133771 or via email: baznaskab.tanatoraja@baznas.go.id. Fifth Box of Infaq: The procurement of these infaq boxes is distributed to several shops that are considered to make a significant contribution for people to donate to.

The fundraising strategy carried out by the Amil Zakat Agency of Tana Toraja Regency, either directly or indirectly, has not been maximal. It needs innovation and creativity carried out by zakat amil to increase the collection of zakat funds. In addition, zakat officers (amil) need training and assistance to raise funds through digital fundraising. It is essential so that the reach of the collection of zakat, infaq, and alms funds carried out by BAZNAS Tana Toraja can be wider, considering that Toraja is a Muslim minority area. Zakat managers need to be open about how they collect and distribute zakat to earn the trust of muzakkis.

\section{SWOT Analysis of Fundraising at the National Amil Zakat Agency of Tana Toraja Regency}

Table 4 SWOT Matrix

\begin{tabular}{|c|c|c|}
\hline IFAS & Strengths (S) & Weaknesses (W) \\
\hline EFAS & $\begin{array}{l}\text { 1. An official government } \\
\text { agency } \\
\text { 2. Strategic office location } \\
\text { in the city center } \\
\text { 3. Have a clear goal } \\
\text { 4. Indonesia is a Muslim- } \\
\text { majority country }\end{array}$ & $\begin{array}{l}\text { 1. Quality and Quantity of } \\
\text { Amil } \\
\text { 2. Still using old } \\
\text { technology } \\
\text { 3. Minimal Operational } \\
\text { Funding } \\
\text { 4. Tana Toraja Muslim } \\
\text { Minority Area }\end{array}$ \\
\hline
\end{tabular}




\begin{tabular}{|c|c|c|}
\hline $\begin{array}{l}\text { Opportunities }(\mathbf{O}) \\
\text { 1. The law of zakat is } \\
\text { obligatory. } \\
\text { 2. Cooperation with } \\
\text { government and private } \\
\text { institutions } \\
\text { 3. Excellent program for } \\
\text { the development of } \\
\text { converts and economic } \\
\text { empowerment of } \\
\text { mustahik } \\
\text { 4. The development of } \\
\text { increasingly advanced } \\
\text { technology }\end{array}$ & $\begin{array}{l}\text { Strategy SO } \\
\text { 1. Expanding the network } \\
\text { of cooperation with the } \\
\text { government and private } \\
\text { institutions } \\
\text { 2. Create excellent work } \\
\text { programs that are an } \\
\text { attraction for muzakki } \\
\text { and munfik to distribute } \\
\text { zakat and infaq } \\
\text { 3. Include the location of } \\
\text { the BAZNAS office, } \\
\text { social media websites, } \\
\text { and google maps to } \\
\text { make it easier for the } \\
\text { public to find the } \\
\text { BAZNAS address if } \\
\text { they want to pay zakat } \\
\text { or donate directly at the } \\
\text { office. }\end{array}$ & $\begin{array}{l}\text { Strategy WO } \\
\text { 1. Participate in education } \\
\text { and training for amil } \\
\text { 2. Development of online } \\
\text { fundraising applications } \\
\text { 3. Increase the number of } \\
\text { amil } \\
\text { 4. Raising muzakki and } \\
\text { munfik throughout } \\
\text { Indonesia } \\
\text { 5. Publish excellent } \\
\text { programs on websites } \\
\text { and other social media }\end{array}$ \\
\hline Threats (T) & Strategy ST & Strategy WT \\
\hline $\begin{array}{l}\text { 1. Public awareness of } \\
\text { zakat is still lacking. } \\
\text { 2. Collaboration with } \\
\text { stakeholders that have } \\
\text { not gone well } \\
\text { 3. Understanding amil as a } \\
\text { profession } \\
\text { 4. Community Traditions }\end{array}$ & $\begin{array}{l}\text { 1. Make socialization to } \\
\text { the community about } \\
\text { the importance of } \\
\text { tithing } \\
\text { 2. Build coordination with } \\
\text { stakeholders, in this } \\
\text { case, the government, } \\
\text { the Indonesian Ulema } \\
\text { Council, and the private } \\
\text { sector } \\
\text { 3. Convincing the public } \\
\text { that BAZNAS is an } \\
\text { institution officially } \\
\text { appointed by the } \\
\text { government and works } \\
\text { professionally and } \\
\text { transparently } \\
\text { 4. Provide the amil that } \\
\text { their profession is noble } \\
\text { and pay attention to } \\
\text { their benefits. }\end{array}$ & $\begin{array}{l}\text { 1. Socializing the virtues } \\
\text { of tithing through the } \\
\text { website and social } \\
\text { media } \\
\text { 2. Creating an excellent } \\
\text { cooperative relationship } \\
\text { between stakeholders } \\
\text { and the community } \\
\text { 3. Discuss with the local } \\
\text { government so that the } \\
\text { operational budget of } \\
\text { BAZNAS can be of } \\
\text { particular concern so } \\
\text { that the amil } \\
\text { performance can be } \\
\text { more professional } \\
\text { 4. Building synergy with } \\
\text { the community that all } \\
\text { programs launched by } \\
\text { BAZNAS are for the } \\
\text { benefit of the ummah }\end{array}$ \\
\hline
\end{tabular}


Based on the data above, the researcher proposes SO, WO, ST, and WT strategies to prioritize human resource development (amil) through education and training, especially technology-based fundraising. due to the lack of competent human resources (amil) in their fields. The quality of amil needs to be developed by including training in zakat processing procedures. Zakat collection is not optimal because the knowledge of Amil about zakat collection strategies is insufficient, so the results are not optimal. An amil zakat is required to have three abilities: zakat fiqh experts, marketing skills, and public speaking (Abduh, 2021).

It is very permissible to know that knowing other sciences other than what is occupied is very permissible to broaden the thoughts and skills of each individual who has become a daily job (Alam et al., 2019). The training that can be followed is training on websites for social institutions, training and mentoring in the use of financial software, zakat empowerment seminars, and zakat functions (Laili \& Reality, 2016). High productivity and performance will be more guaranteed if the organization has the right way to maintain Amilin's professionalism (Case et al., 2015).

In addition, it is also essential that the central BAZNAS or the provincial BAZNAS provide a particular budget to the Tana Toraja Regency BAZNAS in terms of operational financing, because the problem is the limited funds collected so that the rights of amil are also limited. It later became one of the causes of Amil, who did not survive in BAZNAS Toraja Regency and considered Amil only a temporary job. At the same time, MUI has set a fatwa for all Zakat Management Organizations to take part in the amil rights, namely MUI Fatwa No. 8 of 2011. Amil rights are taken from zakat within reasonable limits or not taken from zakat and can be taken from other funds, not from zakat. Amil Zakat, who has received a salary from the state or private institutions in their duties as Amil, is not entitled to receive a share of the zakat funds that are part of the Amil, while zakat Amil who does not receive a salary from the state or private institutions is entitled to receive a share of the zakat funds that are part of the Amil as part of the zakat fund. Compensation based on the principle of fairness (Dianti \& Suprayogi, 2018)

Increasing the recovery of Zakat and Infaq funds requires synergy between the government, the Indonesian Ulema Council, the private sector, and the community. The Tana Toraja National Amil Zakat Agency needs to clean up and evaluate all the collection strategies it implements. It's time for the collection to be done digitally. In today's digital era, technology is growing. This rapid development has brought major changes in all lines and aspects. If OPZs stick to traditional funding mechanisms in this digital era, their contributions will not increase, and they may even tend to be less effective. On the other hand, if the OPZ changes through the use of technology and digital media, especially in terms of funding, this will have a positive impact on the socialization program implemented (Rohim, 2019).

Today's internet users have made digital fundraising channels the focus of their attention for OPZ. OPZ parties must optimize digital fundraising channels such as websites, email marketing, search engine marketing, social media marketing, and social networking. This channel needs to be used by OPZ in order to convey various zakat management programs, 
especially related to the zakat collection (Rohim, 2019). In addition, of course, socialization is necessary to educate the public regarding the obligation to pay tithe. The use of social media platforms that are increasingly used by the community requires special efforts to approach donors (Kharima et al., 2021).

Internet users are currently focusing their digital funding channels on OPZs. OPZ stakeholders need to optimize digital funding channels such as websites, email marketing, search engine marketing, social media marketing, and social networking. This channel needs to be used by OPZ to mediate various zakat management programs, especially those related to zakat collection (Santoso, 2019). And, of course, socialization is needed to educate the public about zakat. The use of social media by a growing community means that special efforts must be made to connect with donors.

From this study, the researcher recommends debriefing and training carried out by the zakat amil BAZNAS Tana Toraja Regency in terms of digital fundraising, considering that Tana Toraja is a Muslim minority district, so that fundraising is not only in the local area but can also reach other areas. Muslims in Tana Toraja should be reached out to so they can understand the need to pay tithe.

\section{CONCLUSION}

The fundraising strategy carried out by BAZNAS in Tana Toraja Regency has not run optimally; this is due to the lack of competent human resources (amil) in their fields. In addition, the Toraja area is also an area with a Muslim minority population. So it is necessary to open a national collection of zakat funds so that data collection on the number of muzakki and hypocrites can be maximized. The synergy between the government, the private sector, and the community is also needed for future development. The Amil Zakat Agency of Tana Toraja Regency must also correct its fundraising strategy. In this era of rapid technological development, digital fundraising channels must be used so that zakat collection can be more optimal. Various technology-based zakat payment channels can be used through e-commerce, online crowdfunding, and digital payment machines. The use of technology will undoubtedly make it easier for Muslims to donate to BAZNAS Tana Toraja. For this reason, it is necessary to conduct training for zakat al-Mil and sustainable socialization.

\section{REFERENCES}

Abduh, M. (2021). HUMAN RESOURCE MANAGEMENT AT AMIL ZAKAT (Case Study at Amil Zakat Institution and Agency in Banten Province). Journal of Islamic Economics, Finance and Banking, 5(1), 53-67.

Alam, U. S., Solahudin, D., \& Yuliani, Y. (2019). Implementation of Human Resource Management in Improving the Quality of Zakat Management of Zakat Center of Ummah. Tadbir: Journal of Dawah Management, 4(2), 207-224. https://doi.org/10.15575/tadbir.v4i2.1613

Baznas, P. (2020). Outlook Zakat 2021.

Bin-Nashwan, S. A., Abdul-Jabbar, H., Aziz, S. A., \& Sarea, A. (2020). Zakah compliance in Muslim countries: an economic and socio-psychological 
perspective. Journal of Financial Reporting and Accounting.

https://doi.org/10.1108/JFRA-03-2020-0057

Bin-Nashwan, S. A., Abdul-Jabbar, H., Aziz, S. A., \& Viswanathan, K. K. (2020). A socio-economic model of Zakah compliance. International Journal of Sociology and Social Policy, 40(3-4), 304-320. https://doi.org/10.1108/IJSSP-11-2019-0240

Carboni, M., Perelli, C., \& Sistu, G. (2017). Developing tourism products in line with Islamic beliefs: insights from Nabeul-Hammamet. Journal of North African Studies, 22(1), 87-108. https://doi.org/10.1080/13629387.2016.1239078

Cokrohadisumarto, W.bin M., Zaenudin, Z., Santoso, B., \& Sumiati, S. (2020). A study of the Indonesian community's behavior in paying zakat. Journal of Islamic Marketing, 11(4), 961-976. https://doi.org/10.1108/JIMA-10-2018-0208

Awaited, D. U., \& Suprayogi, N. (2018). MANAGEMENT OF OPERATIONAL COSTS OF LAZNAS SURABAYA. Journal of Islamic Economics Theory AndApplied, Vol. 5 No.

Fathonih, A., Maylawati, D. S., \& Ramdhani, M. A. (2019). Model-view-controller approach for e-Zakah. Indonesian Journal of Electrical Engineering and Computer Science, 15(2), 1054-1065. https://doi.org/10.11591/ijeecs.v15.i2.pp1054-1065

Case, S., Badan, D. I., Zakat, A., Bogor, K., Institution, D. A. N., \& Zakat, A. (2015). M. Trust. 1,113-130.

Kharima, N., Muslimah, F., \& Anjani, A. D. (2021). Islamic Philanthropy Strategy Based on Digital Media. EMPATHY: Journal of Social Welfare Sciences, 10(1), 45-53. https://doi.org/10.15408/empati.v10i1.20574

Laili, N. Z., \& Reality, T. Ni. (2016). Research and Development of Human Resource Management Quality System at Amil Zakat, Infaq, and Shodaqoh Institute (LAZIS). Proceedings SNA MK, 175-188.

http://akuntansi.polinema.ac.id/contents/19 PROSIDING SNA MK, Nur Zahrotul Laili.pdf

Listanti, M., Nurdin, R., \& Hasnita, N. (2021). Analysis of Fundraising Strategy in Optimizing Zakat Acceptance in Baitul Mal West Aceh Regency. Journal of Sharia ... https://journal.ar-raniry.ac.id/index.php/JoSE/article/view/1272

Mahmood, K., Hameed, A., \& Jalaluddin Haider, S. (2005). Library fundraising in Pakistan. Library Management, 26, 429-438. https://doi.org/10.1108/01435120510631729

Nopiardo, W. (2018). Zakat Fund Fundraising Strategy in Baznas Tanah Datar Regency. Imara: JOURNAL OF ISLAMIC ECONOMICRESEARCH, 1(1), 57. https://doi.org/10.31958/imara.v1i1.991

Owoyemi, M. Y. (2020). Zakat management: The crisis of confidence in zakat agencies and the legality of giving zakat directly to the poor. Journal of Islamic Accounting and Business Research, 11(2), 498-510. https://doi.org/10.1108/JIABR-07-20170097

Rahmat, R. S., \& Nurzaman, M. S. (2019). Assessment of zakat distribution: A case study on zakat community development in Bringinsari village, Sukorejo district, Kendal. International Journal of Islamic and Middle Eastern Finance and Management, 12(5), 743-766. https://doi.org/10.1108/IMEFM-12-2018-0412

Rijali, A. (2018). Qualitative Data Analysis Ahmad Rijali UIN Antasari Banjarmasin. 17(33), 81-95. 
Rohim, A. N. (2019). Optimization of Zakat Collection Through Digital Fundraising. Al-Balagh: Journal of Da'wah and Communication, 4(1), 59. https://doi.org/10.22515/balagh.v4i1.1556

Said, S.M. (2020). Zakat Management at the National Amil Zakat Agency of Tana Toraja Regency. http://repository.iainpalopo.ac.id/id/eprint/2682/1/SUDIRMAN M. SAID.pdf

Samad, A., \& Glenn, L.M. (2010). Development of Zakah and Zakah coverage in monotheistic faiths. International Journal of Social Economics, 37(4), 302-315. https://doi.org/10.1108/03068291011025264

Santoso, I. R. (2019). Strategy for Optimizing Zakat Digitalization in Alleviation Poverty in the Era of Industrial Revolution 4.0. Ikonomika, 4(1), 35-52. https://doi.org/10.24042/febi.v4i1.3942

Sawmar, A. A., \& Mohammed, M. O. (2021). Enhancing zakat compliance through good governance: a conceptual framework. ISRA International Journal of Islamic Finance, ahead-of-p(ahead-of-print). https://doi.org/10.1108/ijif-10-2018-0116

Yaacoub, H. K., Kfoury, J. El, Ayoub, E., \& Rihana, L. (2015). Fundraising for life: the children's cancer center of Lebanon. Emerald Emerging Markets Case Studies, 5(6), 1-15. https://doi.org/10.1108/EEMCS-12-2014-0298 